\title{
ВИВЧЕННЯ АМІНОКИСЛОТНОГО СКЛАДУ ЗБОРУ ЛІКАРСЬКИХ РОСЛИН 3 АНТИДІАБЕТИЧНОЮ АКТИВНІСТЮ
}

\footnotetext{
Вступ. Цукровий діабет є однією з пріоритетних проблем ВООЗ, які вимагають негайного вирішення, оскільки епідеміологічна ситуація набуває тривожних масштабів - кількість хворих щороку стрімко зростає, що призводить до збільшення інвалідизації та смертності населення через розвиток мікро- $і$ макроангіопатії. 3 метою вирішення цієї проблеми варто здійснювати оптимізацію існуючої орармакотерапії, зокрема за допомогою фрітозборів, що зможуть впливати на різні ланки патогенетичного механізму розвитку даного захворювання та його ускладнень завдяки широкому спектру біологічно активних речовин. У цьому відношенні особливої уваги заслуговують амінокислоти, оскільки відіграють ключову роль у численних обмінних процесах.

Мета дослідження - вивчити якісний склад і встановити кількісний вміст амінокислот у антидіабетичному рослинному зборі, обгрунтувати їх ефективність для лікування та профрілактики цукрового діабету.

Методи дослідження. Якісний склад та кількісний вміст амінокислот визначали методом газової хромато-мас-спектрометрії.

Результати й обговорення. Під час дослідження було ідентифріковано 8 вільних амінокислот - аланін, гліцин, валін, треонін, ізолейцин, пролін, аспарагінову кислоту, сренілаланін та 12 зв'язаних - аланін, гліцин, валін, лейцин, треонін, ізолейцин, пролін, аспарагінову і глутамінову кислоти, френілаланін, лізин, тирозин. Встановлено, що досліджуваний рослинний збір у найбільшій кількості містив лейцин (11,92 мг/2) у зв'язаній фрормі, а також пролін у вільному та зв'язаному стані (7,67 і 11,10 мг/2 відповідно).

Висновки. Результати хроматографрічного дослідження свідчать про достатній вміст амінокислот, зокрема незамінних, що мають здатність стимулювати секрецію інсуліну, знижувати гіперглікемію та регулювати метаболічні процеси у хворих на цукровий діабет. У рослинному антидіабетичному зборі переважав такий амінокислотний компонент, як лейцин, есенціальна амінокислота з найбільш вираженою інсуліновою секретолітичною активністю.
}

КЛЮЧОВІ СЛОВА: амінокислоти; рослинний антидіабетичний збір; газова хромато-мас-спектрометрія; цукровий діабет.

ВСТУП. Цукровий діабет є однією з пріоритетних проблем ВООЗ, які вимагають негайного вирішення, оскільки епідеміологічна ситуація набуває тривожних масштабів - кількість хворих щороку стрімко зростає, що призводить до збільшення інвалідизації та смертності населення через розвиток макро- і мікроангіопатії [1]. Згідно 3 офріційними даними Міжнародної фредерації діабету (2019), прогнозується збільшення захворюваності на діабет у світі в 1,5 раза до 2030 р., що становитиме понад 500 тисяч пацієнтів [2]. Тому оптимізація існуючої протидіабетичної формакотерапії, пошук та вивчення нових препаратів для профрілактики і лікування цієї хвороби та її ускладнень $€$ важливим питанням сучасної фрармації і медицини.

(c) А. О. Савич, С. М. Марчишин, Т. І. Лемішка, 2020.
Одним із таких напрямків може бути використання фотозасобів як у вигляді монотерапії на легких стадіях захворюваності та для ії профілактики, так і в поєднанні з традиційною терапією при більш тяжких фрормах захворювання. Фітотерапія є перспективним та обґрунтованим методом, оскільки має ряд переваг, таких, як відносно низька токсичність рослинних препаратів, м'який фармакологічний ефект і можливість застосовувати протягом тривалого періоду без значних побічних ефеектів, здатність добре поєднуватися із синтетичними препаратами, широкий спектр біологічно активних речовин 3 різними механізмами впливу на організм людини та широкий діапазон фармакологічної активності [3]. Особливої уваги заслуговують комбінації різних лікарських рослин, оскільки за раху- 
нок поєднання певних рослинних компонентів можна тим чи іншим чином впливати на патогенез і прогресування хвороби, в даному випадку цукрового діабету, що є хронічним захворюванням зі складним патогенетичним механізмом розвитку, тяжким перебігом та ускладненим діабетичними ангіопатіями [4-7]. Тому з метою встановлення кореляційних зв'язків між фрітохімічним складом досліджуваного рослинного збору та його антидіабетичною активністю, яку було вивчено в попередніх дослідженнях [8, 9], доцільно провести фрітохімічний аналіз, зокрема, амінокислот як одних з найбільш важливих біологічно активних речовин у терапії цукрового діабету.

Амінокислоти, крім своєї основної функції попередників синтезу протеїну, відіграють ключову роль у численних обмінних процесах, адже мають потужну секретолітичну активність - стимулюють секрецію інсуліну, глюкагону, кортизолу та інсуліноподібного фрактора росту-1 [10]. Крім того, дані літератури свідчать про регуляторну роль амінокислот у транскрипції та трансляції генів, а також про їх важливу фрункцію у внутрішньоклітинній передачі сигналів [10, 11]. Ефективність амінокислот у лікуванні та профрілактиці цукрового діабету зумовлена насамперед їх здатністю стимулювати секрецію інсуліну в $\beta$-клітинах підшлункової залози, а також підвищувати утилізацію глюкози у крові та знижувати аліментарну гіперглікемію. Найбільший інсулінотропний ефрект притаманний аргініну, лейцину, ізолейцину, аланіну та френілаланіну [11, 12]. Крім цього, амінокислоти можуть зменшувати протеоліз м'язів та/або стимулювати синтез протеїну, що приводить до поліпшення білкового балансу в скелетних м'язах, що збільшує процес утилізації глюкози. Це є важливою складовою терапії цукрового діабету, адже такі хворі часто мають дефіцит маси скелетних м'язів, що, у свою чергу, сприяє розвитку інсулінорезистентності та прогресуванню даного захворювання [10]. Тому метою нашого дослідження було вивчити якісний склад і встановити кількісний вміст амінокислот у антидіабетичному рослинному зборі, обґрунтувати їх ефрективність для лікування та профрілактики цукрового діабету.
МЕТОДИ ДОСЛІДЖЕННЯ. ПіД час дослідження було використано рослинну сировину, заготовлену в червні - серпні 2019 р. на Тернопільщині (Україна). Після збирання сировину сушили, подрібнювали та приводили до стандартного стану відповідно до вимог ДФУ 2.0 [13]. Рослинний збір формували згідно з його компонентним складом (табл. 1).

Якісний склад та кількісний вміст амінокислот у досліджуваній сировині визначали методом газової хромато-мас-спектрометрії (ГХ-МС) за допомогою системи Agilent 6890N/5973inert (Agilent technologies, США) [14]. Хроматографрічне розділення проводили з використанням капілярної колонки НP-5ms (30 m×0,25 mm×0,25 km, Agilent technologies, США) в режимі програмування температури - початкову температуру $50{ }^{\circ} \mathrm{C}$ витримували впродовж 4 хв, підвищували з градієнтом $5^{\circ} \mathrm{C} /$ хв до $300^{\circ} \mathrm{C}$, кінцеву температуру витримували протягом 5 хв. Температура випаровувача становила $250{ }^{\circ} \mathrm{C}$, температура інтерфейсу $-280{ }^{\circ} \mathrm{C}$. Пробу об'ємом 1 мкл вводили в режимі поділу потоку 1:50. Детектування здійснювали в режимі SCAN у діапазоні (38400 m/z). Швидкість потоку газу-носія через колонку становила 1,0 мл/хв.

Пробопідготовку рослинної сировини для визначення вільних амінокислот проводили таким чином: наважку, перетерту до порошкоподібного стану, поміщали у віалу, додавали 2 мл водного розчину 0,1N хлористоводневої кислоти та витримували на ультразвуковій бані за температури $50{ }^{\circ} \mathrm{C}$ протягом 3 год. Потім 1,0 мл відцентрифугованого екстракту упарювали на роторному випаровувачі, тричі промиваючи водою очищеною Р для видалення хлористоводневої кислоти.

Пробопідготовку рослинної сировини для визначення зв'язаних амінокислот проводили таким чином: наважку, перетерту до порошкоподібного стану, поміщали у віалу, додавали 2 мл водного розчину 6N хлористоводневої кислоти та поміщали в термостат за температури $110^{\circ} \mathrm{C}$. гідроліз виконували протягом 24 год. Потім 1,6 мл відцентрифругованого гідролізату упарювали на роторному випаровувачі, тричі проми-

Таблиця 1 - Компонентний склад рослинного антидіабетичного збору

\begin{tabular}{||l|c|c||}
\hline \multicolumn{1}{|c|}{ Компонент } & Вміст, г & $\begin{array}{c}\text { Співвідношення } \\
\text { масових часток }\end{array}$ \\
\hline Inulae rhizomata rt radices & 10,0 & 1 \\
\hline Helichrysi arenarii flores & 20,0 & 2 \\
\hline Maydis style cum stigmatis & 20,0 & 2 \\
\hline Origani herba & 20,0 & 2 \\
\hline Rosae majalis fructus & 20,0 & 2 \\
\hline Taraxaci radices & 10,0 & 1 \\
\hline
\end{tabular}


ваючи водою очищеною Р для видалення хлористоводневої кислоти.

Преколонкову дериватизацію проводили шляхом розчинення сухих зразків у реакційній суміші, що складалася з 390 мкл розчину 1 М натрію гідроксиду, 333 мкл метанолу і 67 мкл піридину, з ретельним перемішуванням протягом 5 с. До одержаного розчину додавали 80 мкл метилхлорофрормату і знову ретельно перемішували протягом 60 с. Утворені деривати амінокислот екстрагували 400 мкл хлоро- форму з подальшим додаванням 400 мкл розчину 50 мМ натрію гідрокарбонату. Для хроматограсрічного аналізу використовували хлорофрормну фразу [15].

Ідентисрікацію амінокислот проводили шляхом порівнювання часів утримання стандартів амінокислот і за наявністю репрезентативних молекулярних та фррагментарних іонів (табл. 2). Вміст зв'язаних амінокислот визначали шляхом віднімання вмісту вільних амінокислот від їх загального вмісту.

Таблиця 2 - Умови хроматографрічної ідентифрікації амінокислот

\begin{tabular}{||l|c|c|c|}
\hline \multicolumn{1}{|c|}{ Амінокислота } & Час виходу, хв & $\begin{array}{c}\text { Молекулярний } \\
\text { іон }(\mathrm{m} / \mathrm{z})\end{array}$ & $\begin{array}{c}\text { Головні фррагментарні іони } \\
(\mathrm{m} / \mathrm{z})\end{array}$ \\
\hline Гліцин & 14,83 & 147 & 88 \\
\hline Аланін & 14,83 & 161 & 102,88 \\
\hline Валін & 18,57 & 189 & $146,130,115,98$ \\
\hline Лейцин & 20,77 & 203 & $176,144,114,100,88$ \\
\hline Серин & 21,04 & 191 & $147,115,100,88$ \\
\hline Треонін & 21,28 & 205 & $144,115,101,88$ \\
\hline Ізолейцин & 21,87 & 203 & 128,84 \\
\hline Пролін & 21,97 & 187 & $146,127,95$ \\
\hline Аспарагін & 22,09 & 262 & $160,128,118,101$ \\
\hline Аспарагінова кислота & 23,93 & 219 & $201,174,142,114$ \\
\hline Глутамінова кислота & 26,90 & 233 & $147,128,115$ \\
\hline Метіонін & 27,14 & 221 & $192,176,158,146,132$ \\
\hline Цистеїн & 29,18 & 192 & $178,162,146,131,103,91$ \\
\hline Фенілаланін & 29,75 & 237 & $141,109,82$ \\
\hline Глутамін & 31,90 & 276 & $244,212,142,88$ \\
\hline Лізин & 35,94 & 276 & $254,226,210,194,140,81$ \\
\hline Гістидин & 37,08 & 285 & 130 \\
\hline Тирозин & 38,94 & 296 & $252,236,220,192,165,146,121$ \\
\hline Триптофран & 42,01 & 276 & \multicolumn{2}{|c|}{} \\
\hline
\end{tabular}

РЕЗУЛЬТАТИЙ ОБГОВОРЕННЯ. РезУЛЬтати Складу рослинного антидіабетичного збору нахроматографрічного визначення амінокислотного ведено на рисунках 1, 2 і в таблиці 3.

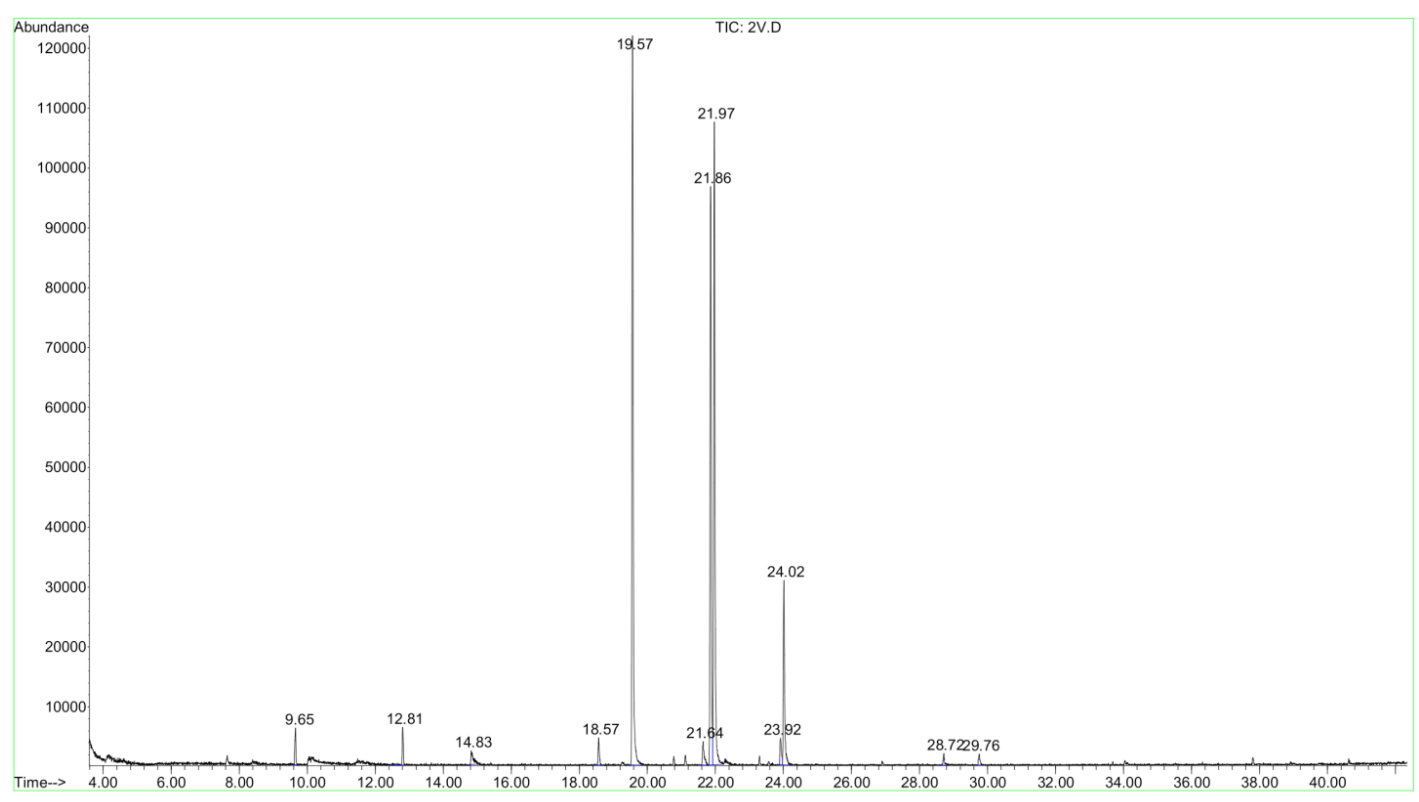

Рис. 1. Хроматограма вільних амінокислот у рослинному антидіабетичному зборі. 


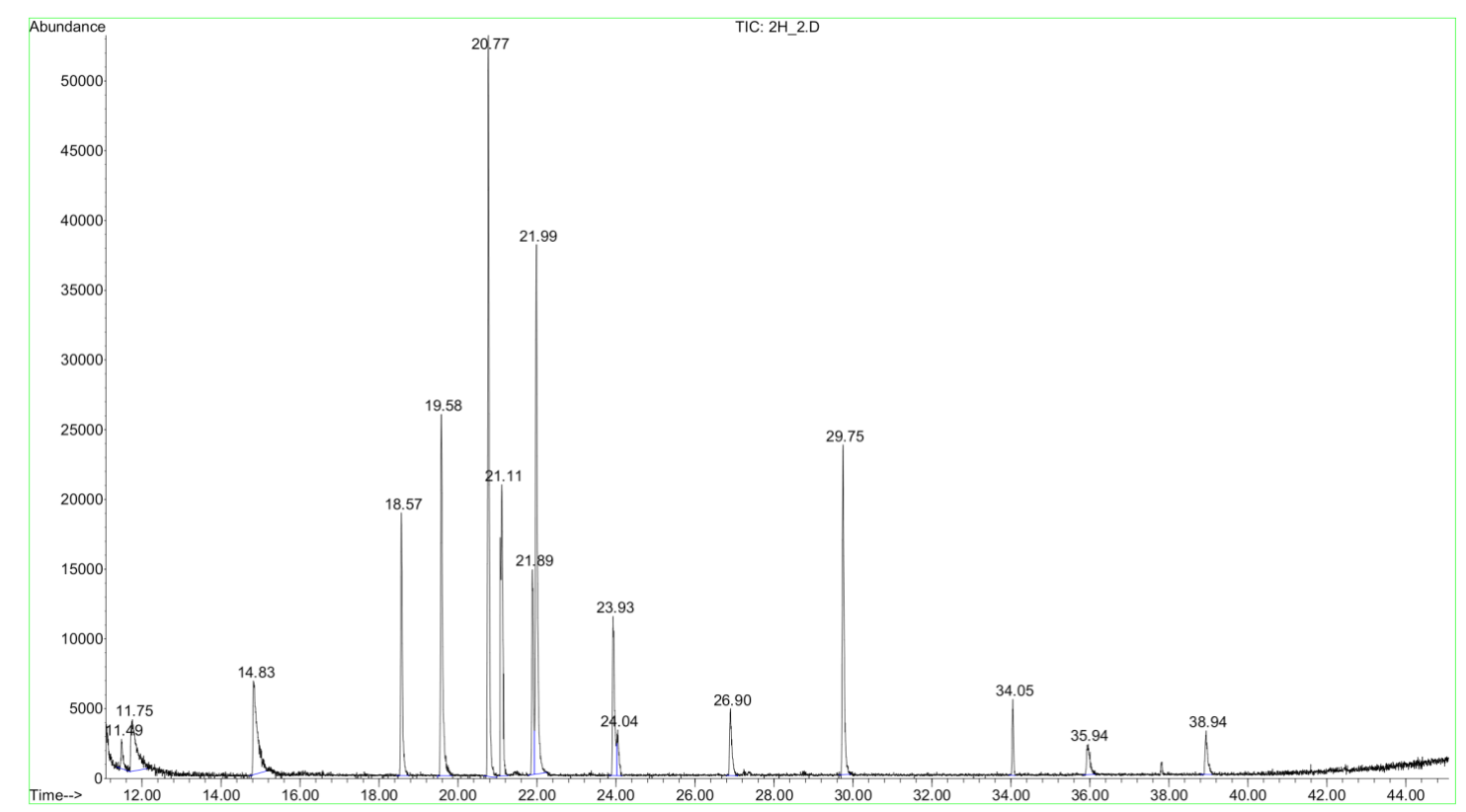

Рис. 2. Хроматограма зв'язаних амінокислот у рослинному антидіабетичному зборі.

Таблиця 3 - Вміст амінокислот у рослинному антидіабетичному зборі

\begin{tabular}{|c|c|c|c|c|c|}
\hline $\begin{array}{l}\text { № } \\
\text { 3/ח }\end{array}$ & Назва & $\begin{array}{c}\text { Час виходу, } \\
\text { хв }\end{array}$ & $\begin{array}{c}\text { Вміст вільних } \\
\text { амінокислот, мг/г }\end{array}$ & $\begin{array}{l}\text { Вміст зв'язаних } \\
\text { амінокислот, мг/г }\end{array}$ & $\begin{array}{l}\text { Загальний } \\
\text { вміст, мг/г }\end{array}$ \\
\hline 1 & Аланін+гліцин & 14,83 & 0,27 & 3,91 & 4,18 \\
\hline 2 & Валін* & 14,83 & 0,29 & 4,37 & 4,66 \\
\hline 3 & Норвалін & 18,57 & \multicolumn{3}{|c|}{ Внутрішній стандарт } \\
\hline 4 & Лейцин* & 20,77 & $H / B$ & 11,92 & 11,92 \\
\hline 5 & Серин & 21,04 & $H / B$ & $H / B$ & $\mathrm{H} / \mathrm{B}$ \\
\hline 6 & Треонін ${ }^{\star}$ & 21,28 & 0,34 & 6,51 & 6,85 \\
\hline 7 & Ізолейцин ${ }^{\star}$ & 21,87 & 6,36 & 4,41 & 10,77 \\
\hline 8 & Пролін & 21,97 & 7,67 & 11,10 & 18,77 \\
\hline 9 & Аспарагін & 22,09 & $H / B$ & $\mathrm{H} / \mathrm{B}$ & $H / B$ \\
\hline 10 & Аспарагінова кислота & 23,93 & 0,36 & 3,23 & 3,59 \\
\hline 11 & Глутамінова кислота & 26,90 & $H / B$ & 1,56 & 1,56 \\
\hline 12 & Метіонін ${ }^{*}$ & 27,14 & $H / B$ & $H / B$ & $H / B$ \\
\hline 13 & Цистеїн & 29,18 & $H / B$ & $H / B$ & $H / B$ \\
\hline 14 & Фенілаланін ${ }^{\star}$ & 29,75 & 0,14 & 5,91 & 6,05 \\
\hline 15 & Глутамін & 31,90 & $H / B$ & $H / B$ & $H / B$ \\
\hline 16 & Лізин & 35,94 & $H / B$ & 1,05 & 1,05 \\
\hline 17 & Гістидин & 37,08 & $H / B$ & $H / B$ & $H / B$ \\
\hline 18 & Тирозин & 38,94 & $H / B$ & 1,10 & 1,10 \\
\hline 19 & Триптофран ${ }^{\star}$ & 42,01 & $\mathrm{H} / \mathrm{B}$ & $\mathrm{H} / \mathrm{B}$ & $\mathrm{H} / \mathrm{B}$ \\
\hline \multicolumn{3}{|c|}{ Вміст незамінних амінокислот } & 7,13 & 33,12 & 40,25 \\
\hline \multicolumn{3}{|c|}{ Загальний вміст } & 15,43 & 55,07 & 70,50 \\
\hline
\end{tabular}

Примітки:

1. * - незамінні амінокислоти.

2. н/в - не виявлено.

За результатами ГХ-МС-аналізу рослинного антидіабетичного збору було ідентисріковано 8 вільних амінокислот - аланін, гліцин, валін, треонін, ізолейцин, пролін, аспарагінову кислоту і фенілаланін, 3 яких 4 незамінні (рис. 1), та 12 зв'язаних амінокислот - аланін, гліцин, валін, лейцин, треонін, ізолейцин, пролін, аспарагінову і глутамінову кислоти, фенілаланін, лізин та тирозин, з яких 5 незамінні (рис. 2).

Кількісне визначення показало, що в рослинному антидіабетичному зборі переважав такий амінокислотний компонент, як пролін, у вільному та зв'язаному стані - 7,67 і 11,10 мг/г відповідно (табл. 3). Пролін проявляє виражену гіпоглікемічну активність, що зумовлена зменшенням вироблення печінкової глюкози внаслідок пригнічення процесів глікогенолізу, глюконеогенезу та активності глюкозо-6-сроссратази [11]. Згідно 
з результатами хроматографічного аналізу, встановлено, що досліджуваний рослинний збір у найбільшій кількості містив лейцин (11,92 мг/г) незамінну амінокислоту, що перебуває у зв'язаному стані (табл. 3). Лейцин - амінокислота 3 розгалуженим ланцюгом, яка відіграє важливу роль у контролі синтезу протеїну та регулюванні метаболізму клітин. Однією 3 найважливіших фрункцій лейцину при цукровому діабеті $є$ те, що він має здатність стимулювати секрецію інсуліну в $\beta$-клітинах підшлункової залози, а також виступає джерелом енергії метаболічних процесів та алостеричним активатором глутаматдегідрогенази для посилення глутамінолізу $[10,12]$. У досліджуваному зборі виявлено значну кількість у вільному стані ізолейцину (6,36 мг/кг), що належить до групи есенціальних амінокислот (табл. 3). Ізолейцин, що є ізомером лейцину, сам по собі не здатний стимулювати синтез інсуліну, проте при поєднанні з лейцином їх секретолітична активність значно зростає, що спричинює більш виражений гіпоглікемічний ефект [10, 12]. Окрім цього, серед зв'язаних у пептиди амінокислот виявлено високий вміст треоніну (6,51 мг/г), френілаланіну (5,91 мг/г), ізолейцину (4,41 мг/г) та валіну (4,37 мг/г). Усі чотири амінокислоти належать до незамінних (табл. 3). Феніл- аланін, ароматична амінокислота, має безпосередній вплив на перебіг цукрового діабету, зокрема за рахунок своєї здатності регулювати вуглеводний метаболізм шляхом стимулювання вивільнення глюканоподібного пептиду-1 (GLP-1), який, у свою чергу, підсилює секрецію інсуліну, інгібує секрецію глюкагону, стимулює проліферацію та неогенез $\beta$-клітин підшлункової залози, зменшує інсулінорезистентність [11]. Отже, рослинні амінокислоти, виявлені в достатній кількості у досліджуваному зборі, мають важливе значення для перебігу та лікування цукрового діабету.

ВИСНОВКИ. Результати хроматографічного дослідження свідчать про достатній вміст амінокислот, зокрема незамінних, що мають здатність стимулювати секрецію інсуліну, знижувати гіперглікемію та регулювати метаболічні процеси у хворих на цукровий діабет. У рослинному антидіабетичному зборі переважає такий амінокислотний компонент, як лейцин (11,92 мг/г), есенціальна амінокислота 3 найбільш вираженою інсуліновою секретолітичною активністю. Отримані дані свідчать про доцільність застосування досліджуваного рослинного збору з метою оптимізації протидіабетичної фрармакотерапії.

\section{СПИСОК ЛІТЕРАТУРИ}

1. American Diabetes Association, Standards of Medical Care in Diabetes. - Diabetes Care. - 2017. 40 (1). - $142 \mathrm{p}$.

2. International Diabetes Federation. IDF Diabetes Atlas. - 2019. - 9th edition, Brussels, Belgium.

3. The role of medicinal plants in the treatment of diabetes: a systematic review /W. Kooti, M. Farokhipour, Z. Asadzadeh [et al.] // Electronic Physician. - 2016. No. 8 (1). - P. 1832-1842.

4. Основні принципи використання лікарських рослин та їх зборів для лікування та профрілактики цукрового діабету 2 типу (Огляд літератури) / А. О. Савич, С. М. Марчишин, Г. Р. Козир, О. Я. Скринчук // Фітотерапія. Часопис. - 2019. - № 4. - С. 43-46.

5. Савич А. О. Дослідження якісного складу та кількісного вмісту фрлавоноїдів у зборах антидіабетичних № 3 і № 4 методом ВЕРХ / А. О. Савич, С. М. Марчишин, Л. О. Кравчук // Актуальні питання фрармац. і мед. науки та практики. - 2020. - 13, № 2 (33). C. 219-224.

6. Савич А. О. Аналіз мінерального складу рослинних антидіабетичних зборів / А. О. Савич, С. М. Марчишин // Мед. та клініч. хімія. - 2020. - 22, № 2 (84). C. 81-86.

7. Savych A. Determination of fatty acid composition content in the herbal antidiabetic collections / A. Savych, S. Marchyshyn, R. Basaraba // Pharmacia. - 2020. No. 67 (3). - P. 153-159.
8. Savych A. Screening of hypoglycemic activity of herbal mixtures (Message 2) / A. Savych, S. Marchyshyn, O. Doroshenko // Ukrainian Biopharmaceutical Journal. 2020. - No. 3 (64). - P. 22- 29.

9. Antihyperglycemic, hypolipidemic and antioxidant properties of the herbal mixtures in dexamethasoneinduced insulin resistant rats / A. Savych, M. Marchyshyn, R. Basaraba, M. Lukanyuk // Pharmacologyonline. 2020. - 2. - P. 73- 82.

10. Comerford K. B. Emerging evidence for the importance of dietary protein source on glucoregulatory markers and type 2 diabetes: different effects of dairy, meat, fish, egg, and plant protein foods / K. B. Comerford, G. Pasin // Nutrients. - 2016. - 8, No. 8. - P. 446.

11. Branched-chain and aromatic amino acid profiles and diabetes risk in Chinese populations / T. Chen, Y. Ni, X. Ma [et al.] // Scientific Reports. - 2016. - 6. - 20594.

12. Application of Raman spectroscopy in type 2 diabetes screening in blood using leucine and isoleucine amino-acids as biomarkers and in comparative anti-diabetic drugs efficacy studies / Z. Birech, P. W. Mwangi, F. Bukachi [et al.] // PloS One. - 2017. - 12, No. 9. P. e0185130.

13. WHO Guidelines on Good Agricultural and Mixture Practices (GACP) for Medicinal Plants. - World Health Organization, Geneva. - 2003. - 72 p.

14. Microscale analysis of amino acids using gas chromatography-mass spectrometry after methyl chlo- 
roformate derivatization / W. P. Chen, X. Y. Yang, A. D. Hegeman [et al.] // Journal of Chromatography B. 2010. - 878, No. 24. - P. 2199-2208.

15. Optimization of a gas chromatography-mass spectrometry method with methyl chloroformate de- rivatization for quantification of amino acids in plant tissue / B. Vancompernolle, K. Croes, G. Angenon // Journal of Chromatography B. - 2016. - 1017. - P. 241249.

\section{REFERENCES}

1. American Diabetes Association, Standards of Medical Care in Diabetes (2017). Diabetes Care, 40 (1), 142.

2. International Diabetes Federation (2019). IDF Diabetes Atlas, 9th edition. Brussels, Belgium.

3. Kooti, W., Farokhipour, M., Asadzadeh, Z., AshtaryLarky, D., \& Asadi-Samani, M. (2016). The role of medicinal plants in the treatment of diabetes: a systematic review. Electronic Physician, 8 (1), 1832-1842.

4. Savych, A.O., Marchyshyn, S.M., Kozyr, H.R., \& Skrinchuk, O.Y. (2019). Osnovni pryntsypy vykorystannya likarskykh roslyn ta yikh zboriv dlia likuvannla ta profilaktyky tsukrovoho diabetu 2 typu [Basic principles of the using of medicinal plants and their collections for treatment and prevention of diabetes mellitus type 2 (literature review)]. Fitoterapiia. Chasopys - Journal Phypotherapy, 4, 43-46 [in Ukrainian].

5. Savych, A.O., Marchyshyn, S.M., \& Kravchuk, L.O. (2020). Doslidzhennia yakisnoho skladu ta kilkisnoho vmistu flavonoyidiv u zborakh antydiabetychnykh № 3 № 4 metodom VERH [Investigation of the qualitative composition and quantitative content of flavonoids in the herbal antidiabetic collections No. 3 and No. 4 by the method of HPLC]. Aktualni pytannia farmatsevtychnoi i medychnoi nauky i praktyky - Current Issues in Pharmacy and Medicine and Practice, 13 (2), 219-224 [in Ukrainian].

6. Savych, A.O., \& Marchyshyn, S.M. (2020). Analiz mineralnoho skladu roslynykh antydiabetychnykh zboriv [Analysis of the mineral composition of herbal antidiabetic mixtures]. Med. i klin. khimiia - Medical and Clinical Chemistry, 22 (2),81-86 [in Ukrainian].

7. Savych, A., Marchyshyn, S., \& Basaraba, R. (2020). Determination of fatty acid composition content in the herbal antidiabetic collections. Pharmacia, 67 (3), 153-59.

8. Savych, A., Marchyshyn, S., \& Doroshenko, O. (2021). Screening of hypoglycemic activity of herbal mixtures (Message 2). Ukrainian Biopharmaceutical Journal, 3 (64), 22-29.

9. Savych, A., Marchyshyn, S., Basaraba, R., \& Lukanyuk, M. (2020). Antihyperglycemic, hypolipidemic and antioxidant properties of the herbal mixtures in dexamethasone-induced insulin resistant rats. Pharmacologyonline, 2, 73-82.

10. Comerford, K.B., \& Pasin, G. (2016). Emerging evidence for the importance of dietary protein source on glucoregulatory markers and type 2 diabetes: different effects of dairy, meat, fish, egg, and plant protein foods. Nutrients, 8 (8), 446.

11. Chen, T., Ni, Y., Ma, X., Bao, Y., Liu, J., Huang, F., Hu, C., Xie, G., Zhao, A., Jia, W., Jia, W. (2016). Branchedchain and aromatic amino acid profiles and diabetes risk in Chinese populations. Scientific Reports, 6, 20594.

12. Birech, Z., Mwangi, P. W., Bukachi, F., \& Mandela, K.M. (2017). Application of Raman spectroscopy in type 2 diabetes screening in blood using leucine and isoleucine amino-acids as biomarkers and in comparative anti-diabetic drugs efficacy studies. PloS One, 12 (9), e0185130.

13. (2003). WHO Guidelines on Good Agricultural and Mixture Practices (GACP) for Medicinal Plants. World Health Organization, Geneva.

14. Chen, W.P., Yang, X.Y., Hegeman, A.D., Gray, W.M., Cohen, J.D. (2010). Microscale analysis of amino acids using gas chromatography-mass spectrometry after methyl chloroformate derivatization. Journal of Chromatography B: Analytical Technologies in the Biomedical and Life Sciences, 878 (24), 2199-2208.

15. Vancompernolle, B., Croes, K., \& Angenon, G. (2016). Optimization of a gas chromatography-mass spectrometry method with methyl chloroformate derivatization for quantification of amino acids in plant tissue. Journal of Chromatography B, 1017, 241-249.

А. А. Савич, С. М. Марчишин, Т. И. Лемишка ТЕРНОПОЛЬСКИЙ НАЦИОНАЛЬНЫЙ МЕДИЦИНСКИЙ УНИВЕРСИТЕТ ИМЕНИ И. Я. ГОРБАЧЕВСКОГО МОЗ УКРАИНЫ

\section{ИЗУЧЕНИЕ АМИНОКИСЛОТНОГО СОСТАВА СБОРА ЛЕКАРСТВЕННЫХ РАСТЕНИЙ С АНТИДИАБЕТИЧЕСКОЙ АКТИВНОСТЬЮ}

\section{Резюме}

Вступление. Сахарный диабет является одной из приоритетных проблем ВОЗ, которые требуют немедленного решения, поскольку эпидемиологическая ситуация приобретает тревожных маситабов количество больных ежегодно стремительно растет, что приводит к увеличению инвалидизации и смертности населения через развитие микро- и макроангиопатии. С челью решения этой проблемы следует осуществлять оптимизацию существующей фрармакотерапии, в частности с помощью фрито- 
сборов, которые смогут влиять на различные звенья патогенетического механизма развития данного заболевания и его осложнений благодаря широкому спектру биологически активных веществ. В этом отношении особого внимания заслуживают аминокислоты, поскольку играют ключевую роль в многочисленных обменных процессах.

Цель исследования - изучить качественный состав и установить количественное содержание аминокислот в противодиабетическом растительном сборе, обосновать их эффрективность для лечения и профилактики сахарного диабета.

Методы исследования. Качественный состав и количественное содержание аминокислот определяли методом газовой хромато-масс-спектрометрии.

Результаты и обсуждение. В ходе исследования было идентифицировано 8 свободных аминокислот - аланин, глицин, валин, треонин, изолейцин, пролин, аспарагиновую кислоту и френилаланин и 12 связанных - аланин, глицин, валин, лейцин, треонин, изолейцин, пролин, аспарагиновую и глутаминовую кислоты, френилаланин, лизин и тирозин. Установлено, что исследуемый растительный сбор в большом количестве содержал лейцин (11,92 мг/2) в связанной форме, а также пролин в свободном и связанном состоянии (7,67 и 11,10 мг/2 соответственно).

Выводы. Результаты хроматографрического исследования свидетельствуют о достаточном содержании аминокислот, в частности незаменимых, обладающих способностью стимулировать секрецию инсулина, снижать гипергликемию и регулировать метаболические процессы у больных сахарным диабетом. В растительном антидиабетическом сборе преобладал такой аминокислотный компонент, как лейцин, эссенциальная аминокислота с наиболее выраженной инсулиновой секретолитической активностью.

КЛЮЧЕВЫЕ СЛОВА: аминокислоты; растительный антидиабетический сбор; газовая хромато-масс-спектрометрия; сахарный диабет.

A. O. Savych, S. M. Marchyshyn, T. I. Lemishka I. HORBACHEVSKY TERNOPIL NATIONAL MEDICAL UNIVERSITY

\section{STUDY OF AMINO ACID COMPOSITION OF MEDICINAL HERBAL MIXTURE WITH ANTIDIABETIC ACTIVITY}

\section{Summary}

Introduction. Diabetes mellitus is one of the priority problems of the WHO, which requires immediate solution, as the epidemiological situation is becoming alarming - the number of patients is growing rapidly each year, leading to increased disability and mortality due to the development of micro- and macroangiopathy. In order to solve this problem, it is necessary to optimize the existing pharmacotherapy, in particular with the help of phytomixtures, which can affect various parts of the pathogenetic mechanism of the disease and its complications due to a wide range of biologically active substances. In this regard, amino acids deserve special attention because they play a key role in many metabolic processes.

The aim of the study - to learn the qualitative composition and quantitative content of amino acids in the herbal antidiabetic mixture and substantiate their effectiveness for the treatment and prevention of diabetes.

Researsch Methods. Determination of the qualitative composition and quantitative content of amino acids was performed by gas chromato-mass-spectrometry.

Results and Discussion. During the study, 8 free amino acids were identified, such as alanine, glycine, valine, threonine, isoleucine, proline, aspartic acid and phenylalanine and 12 related, such as alanine, glycine, valine, leucine, threonine, isoleucine, proline and proline, aline, phenylalanine, lysine and tyrosine. It was found that the studied herbal mixture contains the largest amount of leucine $(11.92 \mathrm{mg} / \mathrm{g})$ in bound form, as well as proline in free and bound form $-7.67 \mathrm{mg} / \mathrm{g}$ and $11.10 \mathrm{mg} / \mathrm{g}$, respectively.

Conclusions. The results of chromatographic examination indicate a sufficient content of amino acids, in particular essential, which have the ability to stimulate insulin secretion, reduce hyperglycemia and regulate metabolic processes in patients with diabetes. The predominant amino acid component in the herbal antidiabetic mixture is leucine, an essential amino acid with the most pronounced insulin secretolytic activity. mellitus.

KEY WORDS: amino acids; herbal antidiabetic mixture; gas chromato-mass-spectrometry; diabetes

Отримано 17.11.20

Адреса для листування: С. М. Марчишин, Тернопільський національний медичний університет імені І. Я. Горбачевського моз України, майдан Волі, 1, Тернопіль, 46001, Україна, e-mail: marchyshyn@tdmu.edu.ua. 